\title{
Why Big Cats Are at High Risk of Extinction Due to Their Exceptional Predatory Abilities: What Conservation Strategies are Needed?
}

\author{
Megan D. Bjordal*
}

\begin{abstract}
Cats have highly specialized physical adaptations for hypercarnivory, placing them among the most feared predators. Unique adaptations include strong skulls, sharp teeth, agile and muscular limbs, a taste only for meat, and hyper-retractable claws. These predator adaptations, which characterize the family Felidae, put Felids at high risk of human conflicts. Nearly all of the big cats have threatened or near threatened conservation statuses and 29 of the 37 Felidae species have decreasing population trends. Conservation strategies that consider the large habitats and herbivores required for these specialized predators are needed.
\end{abstract}

Keywords: Felidae, Panthera, hypercarnivory, Felid conservation

Cats evolved as apex predators and have remained relatively unchanged in physical structure for the last thirty million years (Chamoli \& Wroe, 2011; Turner \& Antón, 1997). Recently, the family Felidae of the order Carnivora has been facing major threats and dramatic population declines, largely due to human conflicts. As the International Union for Conservation of Nature (IUCN; 2013) identifies habitat loss as the greatest threat to mammals as a whole, Felidae species with small home ranges should have greater success in adapting to current pressures than those with large ranges.
In this paper, I review how physical adaptations of Felids lead to their roles as apex predators, and why these highly conserved predatory adaptations may now be contributing to the declines of Felidae species. I theorize that large species, such as those that belong to the genus Panthera, will be most at risk, due to the conflicts they have with humans. These large predators may occasionally kill livestock or attack people, creating animosity towards them. To explore this idea, this paper has a special focus on the genus Panthera, evaluating the ability of these top cats to adapt to current selective pressures, and discussing what conservation strategies need to be implemented to ensure

*Department of Biology, College of Arts and Science, University of Saskatchewan, Saskatoon, SK, Canada

Correspondence: meg.bjordal@usask.ca 
their future survival. In order to develop effective conservation strategies, a thorough understanding of Felids specialized adaptations, phylogeography, current threats, and present status is needed (Barnett, Yamaguchi, Barnes, \& Cooper, 2006; O’Brien \& Johnson 2005).

\section{Predator Adaptations}

Felids have many physical adaptations to provide them with extraordinary predatory abilities. Multiple skull and dentition adaptations give rise to Felids' ability for hypercarnivory, which is the ability to feed almost exclusively on meat. Common themes include many attachments for large craniomandibular muscles for bite strength and sharp-edged carnassial teeth for shearing prey (Diogo et al., 2012; Sicuro, 2011; Van Valkenburgh, 1991; Wroe, McHenry, \& Thomason, 2005). In an analysis of 33 Felid species skulls, Sicuro (2011) identified five distinct patterns plus a generalized cat skull pattern (Table 1), which all had an "ecomorphological fit to hypercarnivory". Felid skulls are all adapted for hypercarnivory, but the size differentiation is likely to avoid niche overlap and prevent competition among species (Sicuro 2011). Large cats, such as those that belong to the genus Panthera, have a wide gape with strong canines and incisors that provide grip and strength when strangle-holding large prey (MeachenSamuels \& Van Valkenburgh, 2009). Felids may not have the strongest bite strength of all the hypercarnivores, as some members of the family Canidae have stronger bite strength when normalized to body mass. However, this in itself may be an adaption to hypercarnivory; cats have a shorter skull than dogs, resulting in reduced bite strength for some species, but providing better resistance to torsion forces created from struggling prey (Wroe et al., 2005).

In addition to skull and dentition adaptations for hypercarnivory, cats have many muscle adaptations. For close-up encounters, cats have powerful and flexible forelimbs to assist with holding and controlling struggling prey (Wroe et al., 2005). Diogo et al. (2012) compared head and neck muscles of the tiger (Panthera tigris) and serval (Leptailurus serval) to other eutherian mammals and found that the tiger and serval have more facial muscle structures, which is an ancient adaptation for carnivory.

One of the most unique adaptations separating Felidae from other mammals is loss of the ability to taste sugars ( $\mathrm{Li}$ et al., 2005; 2006). Cats do not have a taste receptor for sweetness, due to pseudogenization of the sweet-receptor gene ( $\mathrm{Li}$ et al. 2005). This pseudogenization of the sweet-receptor gene is not seen in the other main group in Carnivora, the Canids (Li et al., 2006). The lack of cravings for sweet carbohydrates contributes to cats' behaviours as top predators (Li et al., 2005).

A few families within the order Carnivora have the ability to retract their claws, largely for protection, but cats are able to hyper-retract their claws. This system allows for more spreading during protraction and both hook-shaped and blade-like claws that ultimately produces a more lethal weapon than is seen in other carnivores (Bryant, Russell, Laroiya, \& Powell, 1996). Interestingly, cheetahs (Acinonyxjubatus) are an exception to this feature, as they do not have retractable claws (Russell \& Bryant, 2001). Cheetahs instead have paw and claw adaptations for traction, contributing to their status as the fastest terrestrial mammal, a skill that is important for their hunting style in which they chase prey at high speed (Russell and Bryant 2001). This hunting method is opposed to that of other felids, which typically ambush their prey (Russell \& Bryant, 2001).

Specialized cranial, muscle and dentition adaptations, loss of a sweet taste receptor, and retractable claws are only some of Felidae adaptations for hypercarnivory. Unfortunately, these unique characteristics that give rise to fierce hunters are creating a disadvantage for big cats in the modern world.

Table 1: Distinct Felidae skull patterns observed by Sicuro (2011) in an analysis of 33 Felidae species, and the corresponding genus or species that best represent these patterns.

\begin{tabular}{l|l}
\hline \multicolumn{1}{c|}{ Felidae Skull Pattern } & \multicolumn{1}{c}{ Genus and/or Species } \\
\hline $\begin{array}{l}\text { snouted/massive-headed } \\
\text { round-headed small cats }\end{array}$ & $\begin{array}{l}\text { Panthera } \\
\text { Leopardus colocolo, Leopardus geoffroyi, Leopardus guigna, Prionailurus } \\
\text { bengalensis, Prionailurus rubiginosus } \\
\text { tapering-headed } \\
\text { stout-headed }\end{array}$ \\
$\begin{array}{l}\text { Neofelis nebulosa, Herpailurus yagouaroundi, Prionailurus planiceps } \\
\text { Acinonyx jubatus, Panthera uncia, Otocolobus manul, Felis margarita, Felis } \\
\text { nigripes } \\
\text { generalized }\end{array}$ & $\begin{array}{l}\text { Prionailurus planiceps } \\
\text { Lynx, Leopardus pardalis, Catopuma temminckii }\end{array}$ \\
\hline \hline
\end{tabular}




\section{Recent Evolution}

The family Felidae has little taxonomic diversification compared to other Carnivora families, such as Canidae (Chamoli \& Wroe, 2011; Van Valkenburgh, 1991). Holliday and Steppan (2004) found that hypercarnivory specialization affects morphological diversity, particularly of the jaws and dentition, but not taxonomic diversity; thus, cats' evolutionary trajectories should not be limited. The youngest cats in Felid evolution are the smaller New World cats, such as the ocelot (Leoparduspardalis; Van Valkenburgh, 1991).

The best evidence of recent adaptations in Felids is observed in the clouded leopard (Neofelisnebulosa).
Christiansen (2008) performed a comparative analysis of the craniomandibular morphology of the clouded leopard and primitive sabercats (Paramachairodus spp.) that gave evidence of similarities between them and divergence between the clouded leopard and other large Felids. One such similarity was the elongated, blade-like canines known as saberteeth (Christiansen, 2008). Other extant Felid species are conical-toothed, exhibiting hypertrophied and blade-like upper canines, with reduced lower canines (Christiansen, 2008; Slater \&Van Valkenburgh, 2008). Arguably, the sabertooth is not a progressive 'new' trait in cats, but simply a regression towards a familiar trait. In my literature review, the clouded leopards' convergence with primitive sabercats is the only known evidence of recent

Table 2: Population trends and IUCN status for the family Felidae. Adapted from IUCN (2015).

\begin{tabular}{|c|c|c|c|}
\hline Species & Common Name & Status & Population Trend \\
\hline Acinonyx jubatus & Cheetah & Vulnerable & decreasing \\
\hline Caracal aurata & African Golden Cat & Vulnerable & decreasing \\
\hline Caracal caracal & Caracal & Least Concern & unknown \\
\hline Catopuma badia & Borneo Bay Cat & Endangered & decreasing \\
\hline Catopuma temminckii & Asiatic Golden Cat & Near Threatened & decreasing \\
\hline Felis bieti & Chinese Mountain Cat & Vulnerable & decreasing \\
\hline Felis chaus & Jungle Cat & Least Concern & decreasing \\
\hline Feilis margarita & Sand Cat & Near Threatened & unknown \\
\hline Felis nigripes & Black-footed Cat & Vulnerable & decreasing \\
\hline Felis silvestris & Wild Cat & Least Concern & decreasing \\
\hline Herpailurus yagouaroundi & Jaguarundi & Least Concern & decreasing \\
\hline Leopardus colocolo & Pampas Cat & Near Threatened & decreasing \\
\hline Leopardus geoffroyi & Geoffroy's Cat & Least Concern & stable \\
\hline Leopardus guigna & Guiña & Vulnerable & decreasing \\
\hline Leopardus jacobita & Andean Cat & Endangered & decreasing \\
\hline Leopardus pardalis & Ocelot & Least Concern & decreasing \\
\hline Leopardus tigrinus & Oncilla & Vulnerable & decreasing \\
\hline Leopardus wiedii & Margay & Near Threatened & decreasing \\
\hline Leptailurus serval & Serval & Least Concern & stable \\
\hline Lynx canadensis & Canada Lynx & Least Concern & stable \\
\hline Lynx lynx & Eurasian Lynx & Least Concern & stable \\
\hline Lynx pardinus & Iberian Lynx & Endangered & increasing \\
\hline Lynx rufus & Bobcat & Least Concern & stable \\
\hline Neofilis diardi & Sunda Clouded Leopard & Vulnerable & decreasing \\
\hline Neofilisnebulosa & Clouded Leopard & Vulnerable & decreasing \\
\hline Otocolobus manul & Pallas's Cat & Near Threatened & decreasing \\
\hline Pardofelis marmorata & Marbled Cat & Near Threatened & decreasing \\
\hline Prionailurus bengalensis & Leopard Cat & Least Concern & stable \\
\hline Prionailurus planiceps & Flat-headed Cat & Endangered & decreasing \\
\hline Prionailurus rubiginosus & Rusty-spotted Cat & Vulnerable & decreasing \\
\hline Prionailurus viverrinus & Fishing Cat & Endangered & decreasing \\
\hline Puma concolor & Puma & Least Concern & decreasing \\
\hline
\end{tabular}


Table 3: Population trend, IUCN status, distribution and habitat tolerance for the family Felidae, genus Panthera. Adapted from IUCN (2015).

\begin{tabular}{|c|c|c|c|c|c|}
\hline Species & $\begin{array}{l}\text { Common } \\
\text { Name }\end{array}$ & Status & $\begin{array}{l}\text { Population } \\
\text { Trend }\end{array}$ & Distribution & $\begin{array}{l}\text { Habitat } \\
\text { Tolerance }\end{array}$ \\
\hline Panthera leo & Lion & Vulnerable & decreasing & sub-Saharan Africa, India & broad \\
\hline Panthera onca & Jaguar & Near Threatened & decreasing & $\begin{array}{l}\text { South America (southern } \\
\text { portion) }\end{array}$ & broad \\
\hline Panthera pardus & Leopard & Near Threatened & decreasing & $\begin{array}{l}\text { Africa, tropical Asia, } \\
\text { Eastern Europe, Middle } \\
\text { East }\end{array}$ & broad \\
\hline Panthera tigris & Tiger & Endangered & decreasing & $\begin{array}{l}\text { tropical Asia, Russia far } \\
\text { East }\end{array}$ & $\begin{array}{l}\text { restricted } \\
\text { (forests) }\end{array}$ \\
\hline Panthera uncia & $\begin{array}{l}\text { Snow } \\
\text { Leopard }\end{array}$ & Endangered & decreasing & mountains of Central Asia & $\begin{array}{l}\text { restricted } \\
\text { (alpine and sub } \\
\text { alpine) }\end{array}$ \\
\hline
\end{tabular}

adaptations in the family Felidae, which suggests that they are not adapting widely or quickly enough to current selective pressures, further putting them at high risk of extinction.

\section{IUCN Status}

For the family Felidae, the International Union for Conservation of Nature and Natural Resources (IUCN) Red List of Threatened Species does species assessments for 37 members. Of those 37 species, seven are listed as Endangered, 10 are Vulnerable, and another eight are Near Threatened (Table $2 ; 3$ ). This translates as 46 percent of species in the family Felidae under threat and another 22 percent nearly threatened (IUCN, 2015). Most of the Felidae species show a declining population trend (Table $2 ; 3$ ). The only large cat that does not have a threatened status is the puma (Table 2). While the puma's population is decreasing, it is currently listed as Least Concern (Table 2), a status that may be due to the fact that it has the most expansive distribution of all the felids (O'Brien \&Johnson, 2005). The only members of Felidae that show a stable population trend are small species, which supports the idea that larger cats are more vulnerable (Table 2).

Members of the genus Panthera represent the largest of the extant cats (Sicuro, 2011). The large cats, especially those of the genus Panthera, are currently among the most at risk Felidae species (O'Brien \& Johnson, 2005). All five of the Panthera species have decreasing populations and threatened conservation statuses (Table 3). Notably, the two species with restricted habitats, tigers and snow leopards, are the most at risk, with an IUCN status of Endangered (Table 3).

\section{Threats}

For Panthera spp. habitat loss and human conflict are the biggest threats to survival (IUCN 2013). Tigers, an endangered species (Table 3), are probably the most feared cats, as they are well known for attacks on people (O'Brien \& Johnson, 2005). Human conflicts involve retaliation for killing livestock, persecution, poaching, and trophy hunting (Datta, Anand, \& Naniwadekar, 2008; Hoogesteijn \& Hoogesteijn, 2008; IUCN, 2013; Tian et al., 2011). With strong predatory adaptations, the large cats are adapted to large prey, which in turn require vast habitat. O'Brien and Johnson (2005) speculate that the big Felids' need for large home ranges are a principal reason for their threatened status. Sabertooths, the prehistoric cats, filled an ecological niche as predators of large prey; this niche is now filled by the genus Panthera (Slater \& Van Valkenburgh, 2008). A potential reason for the extinction of the large sabertooth cats was the loss of their large prey (Van Valkenburgh, 1991), another threat which today's big cats may face as human development encroaches on both their habitat and their preys'. Due to low genetic diversity among Felidae species, disease also poses a major threat (IUCN, 2013; O'Brien \& Johnson, 2005). The naturalist David Quamman (2003) predicts that by 2150 large predators like the tiger will no longer exist in the wild due to human activities.

\section{Conservation}

Conservation of Felids is a complex issue and effective management strategies must take their unique predatory adaptations into consideration (Hoogesteijn \& Hoogesteijn, 2008; O'Brien \& Johnson, 2005; Wegge, Odden, Pokharel, \& Storaas, 2009). Given big cats' reliance on large prey, particularly ungulates, effective conservation strategies University of Saskatchewan Undergraduate Research Journal 
need to account for effects on both the cats and non-target species (Wegge et al., 2009). Cats help to keep the populations of their primarily herbivore prey under control, thus indirectly controlling consumption of vegetation (Estes et al., 2011). With the loss of apex predators, a trophic cascade occurs, causing the loss of diverse vegetation and eventually the animals that relied on it for food or habitat (Estes et al., 2011). Trophic cascades can have devastating and irreversible consequences for ecological communities (Estes et al., 2011). In order to prevent further widespread trophic downgrading of entire ecosystems, conservation of apex predators, such as Felids, needs to be improved.

As urban and agricultural landscapes expand alongside a rapidly growing human population, conserving more suitable land with sufficient prey for large Felids is required (Hoogesteijn \& Hoogesteijn 2008; Joshi, Vaidyanathan, Mondol, Edgaonkar, \& Ramakrishnan, 2013; Wegge et al., 2009). Compared to other carnivores, such as the coyote (Canislatrans), red fox (Vulpesvulpes), and raccoon (Procyon lotor), cats-beyond the domestic species (Feliscatus) - have not adapted to living in urban landscapes (Bateman \& Fleming, 2012). Urban and agricultural development creates fragmented land; connections of these fragments are needed, especially for tiger conservation (Joshi et al., 2013; Tian et al., 2011). Effective conservation strategies will require long term wildlife monitoring (Datta et al., 2008).

Excellent examples of conservation strategies which take into account cats' predatory abilities are those which work with farmers to find humane ways to prevent big cats from killing livestock. One such strategy is suggested by Hoogesteijn \& Hoogesteijn (2008), who identify that livestock mortality due to jaguars and pumas in Venezuela needs to be reduced, in order to increase human tolerance of the predatory cats. The suggested solution is to increase buffalo and decrease cattle farming, as buffalos will display defensive behaviour, so are less likely to be preyed on.

Datta et al. (2008) cite illegal hunting as both an indirect and direct threat to large Felids, with education and socio-economic considerations of the local people being the key to prevention. Hunting can either directly kill the big cats or indirectly affect them by removing their prey (Datta et al., 2008; Tian et al., 2011). Laws likely hold little power to prevent hunting of big cats, due to cultural traditions and the need for communities with inadequate resources to provide for themselves (Datta et al., 2008). Species such as tigers are highly valuable in illegal markets (Datta et al., 2008). Involving local communities in conservation efforts and addressing their socio-economic needs is potentially an effective way to reduce illegal hunting (Datta et al., 2008; Joshi et al., 2013).

Low genetic diversity can also hinder conservation efforts; thus, a better understanding of large cat genetics is needed (Barnett et al., 2006; O’Brien \& Johnson, 2005).
Molecular genetics plays a large role in conservation of cats, due to the low genetic diversity of some species, especially tigers and cheetahs, and the valuable information it can reveal about phylogeography, systematics, coalescent dating, ecology, disease, gene mapping, and forensics (Barnett et al., 2006; O'Brien \& Johnson, 2005).

The most controversial but potentially highly beneficial conservation strategy for large Felids was suggested by Donlan (2005), whereby large spaces in North America would be "re-wilded" with large vertebrate species, including large cats. The purpose of this unique conservation strategy would be to re-establish an ecosystem similar to that in the Pleistocene (Donlan, 2005). The project would be implemented with managed ecosystem manipulations and introductions of extant species which are closely related to extinct megafauna (Donlan, 2005). An early stage would introduce African cheetahs and lions, relatives of the North American cheetahs and lions (Donlan, 2005). This proposed conservation approach aims to preserve what large mammals are left and restore evolutionary and ecological potential from the Pleistocene (Donlan, 2005). However, this conservation strategy is risky due to the large financial cost and potential negative impacts to present day ecosystems, such as loss of native species (Rubenstein, Rubenstein, Sherman, \& Gavin, 2006).

\section{Conclusion}

Clearly, the family Felidae and especially the genus Panthera are in trouble. Their already threatened populations are declining. Felids have highly conserved predatory adaptations and have shown few evolutionary changes in the last thirty million years, suggesting that their ability to adapt to current selective pressures is poor. The small cats are the youngest evolutionary Felidae species, and they may survive due to smaller habitat ranges, less human persecution, and reduced predatory conflicts with humans. Larger species, particularly Panthera spp. who require large ranges and present conflicts with people through their extreme predatory abilities and needs as an obligate carnivore, are at high risk of extinction. In order to ensure future survival of Panthera spp., important apex predators, more consideration of their extraordinary adaptations to hypercarnivory is required. 


\section{References}

Barnett, R., Yamaguchi, N., Barnes, I., \& Cooper, A. (2006). The origin, current diversity and future conservation of the modern lion (Panthera leo). Proceedings of the Royal Society of London B: Biological Sciences, 273(1598), 2119-2125. doi: $10.1098 / \mathrm{rspb} .2006 .3555$

Bateman, P. W., \& Fleming, P. A. (2012). Big city life: carnivores in urban environments. Journal of Zoology, 287(1), 1-23. doi:10.1111/j.14697998.2011.00887.x

Bryant, H. N., Russell, A. P., Laroiya, R., \& Powell, G. L. (1996). Claw retraction and protraction in the Carnivora: skeletal microvariation in the phalanges of the Felidae. Journal of morphology, 229(3), 289308. DOI: 10.1002/(SICI)10974687(199609)229:3<289::AID-JMOR4>3.0.CO;2-U

Chamoli, U., \& Wroe, S. (2011). Allometry in the distribution of material properties and geometry of the felid skull: Why larger species may need to change and how they may achieve it. Journal of Theoretical Biology, 283(1), 217-226. doi: 10.1016/j.jtbi.2011.05.020

Christiansen, P. (2008). Evolutionary convergence of primitive sabertooth craniomandibular morphology: the clouded leopard (Neofelis nebulosa) and Paramachairodus ogygia compared. Journal of Mammalian Evolution, 15(3), 155-179. doi: 10.1007/s10914-007-9069-z

Datta, A., Anand, M. O., \& Naniwadekar, R. (2008). Empty forests: Large carnivore and prey abundance in Namdapha National Park, north-east India. Biological Conservation, 141(5), 1429-1435. doi: 10.1016/j.biocon.2008.02.022

Diogo, R., Pastor, F., De Paz, F., Potau, J. M., Bello-Hellegouarch, G., Ferrero, E. M., \& Fisher, R. E. (2012). The head and neck muscles of the serval and tiger: homologies, evolution, and proposal of a mammalian and a veterinary muscle ontology. The Anatomical Record, 295(12), 2157-2178.

Donlan, J. (2005). Re-wilding north America. Nature, 436(7053), 913-914. doi:10.1038/436913a
Estes, J. A., Terborgh, J., Brashares, J. S., Power, M. E., Berger, J., Bond, W. J., ... \& Marquis, R. J. (2011). Trophic downgrading of planet Earth.

Science, 333(6040), 301-306. DOI: $10.1126 /$ science.1205106

Holliday, J. A., \& Steppan, S. J. (2004). Evolution of hypercarnivory: the effect of specialization on morphological and taxonomic diversity. Paleobiology, 30(01), 108-128.

Hoogesteijn, R., \& Hoogesteijn, A. (2008). Conflicts between cattle ranching and large predators in Venezuela: could use of water buffalo facilitate felid conservation?. Oryx, 42(01), 132-138. doi:10.1017/So030605308001105

International Union for Conservation of Nature and Natural Resources (IUCN). (2013). IUCN Red List Status. Retrieved from http://www.iucnredlist.org/initiatives/mammals /analysis/red-list-status.

International Union for Conservation of Nature and Natural Resources (IUCN). (2015) IUCN Red List Of Threatened Species Version 2015.4. Retrieved from: http://www.iucnredlist.org/

Joshi, A., Vaidyanathan, S., Mondol, S., Edgaonkar, A., \& Ramakrishnan, U. (2013). Connectivity of tiger (Panthera tigris) populations in the humaninfluenced forest mosaic of Central India. PloS one, 8(11), e77980. DOI: 10.1371/journal.pone.0077980

Li, X., Li, W., Wang, H., Bayley, D. L., Cao, J., Reed, D. R., ... \& Brand, J. G. (2006). Cats lack a sweet taste receptor. The Journal of nutrition, 136(7), 1932S1934 S.

Li, X., Li, W., Wang, H., Cao, J., Maehashi, K., Huang, L., ... \& Brand, J. G. (2005). Pseudogenization of a sweetreceptor gene accounts for cats' indifference toward sugar. PLoS Genet, 1(1), e3. DOI: 10.1371/journal.pgen.0010003

Meachen-Samuels, J., \& van Valkenburgh, B. (2009). Craniodental indicators of prey size preference in the Felidae. Biological Journal of the Linnean Society, 96(4), 784-799. DOI: 10.1111/j.10958312.2008.01169.x 
O’Brien, S. J., \& Johnson, W. E. (2005). BIG CAT GENOMICS*. Annual Review Genomics Human Genetics, 6, 407-429.

doi: 10.1146/annurev.genom.6.080604.162151

Quammen, D. (2004). Monster of God: The Man-Eating Predator in the Jungles of History and the Mind. New York, NY: WW Norton \& Company.

Rubenstein, D. R., Rubenstein, D. I., Sherman, P. W., \& Gavin, T. A. (2006). Pleistocene Park: Does rewilding North America represent sound conservation for the 21st century?. Biological Conservation, 132(2), 232-238. doi:10.1016/j.biocon.2006.04.003

Russell, A. P., \& Bryant, H. N. (2001). Claw retraction and protraction in the Carnivora: the cheetah (Acinonyx jubatus) as an atypical felid. Journal of Zoology, 254(01), 67-76. doi: http://dx.doi.org/10.1017/So952836901000565

Sicuro, F. L. (2011). Evolutionary trends on extant cat skull morphology (Carnivora: Felidae): a three-dimensional geometrical approach. Biological Journal of the Linnean Society, 103(1), 176-190. doi: 10.1111/j.10958312.2011 .01636 .

Slater, G. J., \& Van Valkenburgh, B. (2008). Long in the tooth: evolution of sabertooth cat cranial shape. Paleobiology, 34(3), 403-419. http://dx.doi.org/10.1666/07061.1

Tian, Y., Wu, J., Smith, A. T., Wang, T., Kou, X., \& Ge, J. (2011). Population viability of the Siberian Tiger in a changing landscape: Going, going and gone?. Ecological modelling, 222(17), 3166-3180. doi:10.1016/j.ecolmodel.2011.06.003

Turner, A., \& Antón, M. (1997). The Big Cats and their Fossil Relatives: An Illustrated Guide to their Evolution and Natural History. New York, NY: Columbia University Press.

van Valkenburgh, B. (1991). Iterative evolution of hypercarnivory in canids (Mammalia: Carnivora): evolutionary interactions among sympatric predators. Paleobiology, 340-362. Retrieved from http://www.jstor.org/stable/2400749
Wegge, P., Odden, M., Pokharel, C. P., \& Storaas, T. (2009). Predator-prey relationships and responses of ungulates and their predators to the establishment of protected areas: a case study of tigers, leopards and their prey in Bardia National Park, Nepal. Biological Conservation, 142(1), 189-202. doi:10.1016/j.biocon.2008.10.020

Wroe, S., McHenry, C., \& Thomason, J. (2005). Bite club: comparative bite force in big biting mammals and the prediction of predatory behaviour in fossil taxa. Proceedings of the Royal Society of London B: Biological Sciences, 272(1563), 619-625. doi: $10.1098 / \mathrm{rspb} .2004 .2986$ 
